\title{
Upsetting the agenda: the clout of external focusing events in the European Council
}

\author{
PETYA ALEXANDROVA \\ Institute of Political Science, Leibniz University Hannover, Germany \\ E-mail: p.alexandrova@ipw.uni-hannover.de
}

\begin{abstract}
Focusing events are sudden, striking large-scale occurrences that attract political attention. However, not all potential focusing events appear on the agenda. Combining data from multiple sources, this study conducts an analysis of the determinants of prioritisation of external focusing events in the European Council over a period longer than two decades. The results demonstrate that decisions regarding the placement of crises on the agenda are underscored by exogenous (humanitarian) and endogenous (geopolitical interest) considerations. Those events with a higher likelihood of agenda access include manmade incidents (versus natural disasters), events with larger death tolls and crises in the neighbourhood. Stronger competition between potential focusing events across time and space reduces the chances of access. The level of attention each event receives depends on purely strategic interests. Focusing events in neighbouring countries gain a higher portion of attention, as do occurrences in states having a larger trade exchange with the European Union.
\end{abstract}

Key words: agenda setting, European Council, European Union, focusing events, foreign affairs

\section{Introduction}

Focusing events are sudden, striking large-scale occurrences that attract the attention of various political and societal actors, often on a global scale. Political leaders regularly respond to such events within and outside the territory of their polity, first and foremost by commenting on the event. This can come in the form of condolences, expressions of sympathy for victims and suffering populations, the condemnation of inhumane acts or an announcement of a particular position towards perpetrators. This initial reaction can later transform into more substantial policy responses, such as the provision of humanitarian aid, involvement in a military coalition or 
even a rethinking of domestic policies. In the European Union (EU), the top institution that can transmit the single voice of the Union to the rest of the world is the European Council. During its regular meetings, which over the years have grown in number, the Heads of State and Government have addressed a multiplicity of issues, and the agenda in many cases had to be readjusted to reflect external focusing events. Prominent cases include the 9/11 terrorist attacks in the United States (US), the outbreak of the Russia-Georgia war in August 2008 and the floods in Pakistan in the summer of 2010.

Although there is some evidence on the conditions under which focusing events influence policy, their relationship with political attention is often taken for granted. However, not all potential focusing events are equally likely to reach the agenda. Even those that are eventually discussed differ in the level of attention they receive. For example, the European Council came up with a declaration on the devastating Iranian earthquake of June 1990, but did not mention even a word about the recent disaster of the same type in Haiti in January 2010. Although the cost of both events was estimated to be relatively similar, the number of causalities and people affected was more than five times bigger in the second case. ${ }^{1}$ Another example can be traced to two terrorist attacks with a comparatively similar number of injured and killed hostages in Russia during the first half of the 2000s. The Beslan school siege (September 2004) was not mentioned in any way in the official account of European Council meetings, whereas the Moscow theatre hostage crisis (October 2002) provoked a declaration full of shock and condemnation.

The reasoning behind making the political decision to discuss a disaster, accident or violent attack occurring abroad is largely unexplored. This article aims to shed light on this area of research by theorising on the conditions under which responsiveness can occur and how more attention can be allocated to an event. The study uses a number of existing datasets and combines data on different kinds of potential focusing events with data on political attention in the European Council. The analysis covers the period 1975-2012, but with data on some of the independent variables beginning only as early as $1988 / 1989$. The article proceeds by explaining what a potential focusing event is and how it relates to attention in political institutions. This is followed by a discussion of the political venue of interest - the European Council. Subsequently, a theory section lays the basis for understanding the logic behind giving attention to focusing events and presents the hypotheses. After a description of the data and the

\footnotetext{
${ }^{1}$ According to the International Emergency Disaster Database, available at http://www. emdat.be/database.
} 
approach, the analysis is described. The article concludes with a discussion of the findings.

\section{Focusing events and agenda setting}

Focusing events occupy a unique place in political agenda setting, as they can disturb the priorities of the day. Their power is often derived from a background of deterioration on a specific issue to which they add urgency by acting as a trigger for attention (Kingdon 2011). This leads to what Downs (1972) conceptualised as an "alarmed discovery". A focusing event can serve to underline the size of a given problem, unlock mismanagement in prevention mechanisms or be a signal for potential future failures. It can present the necessary conditions for redefining an issue, which would then allow it to appear on the top political agenda (Princen 2011).

Calling something a focusing event means that the occurrence has already attracted attention. In order to examine what characteristics of the event and its context trigger a sense of urgency in attention, one should first define a potential focusing event. In his seminal work, Birkland proposed the following definition: "an event that is sudden, relatively rare, can be reasonably defined as harmful or revealing the possibility of potential future harms, inflicts harms or suggests potential harms that are or could be concentrated on a definable geographical area or community of interest, and that is known to policy makers and the public virtually simultaneously" $(1997,22)$. In short, the crucial traits of potential focusing events are suddenness, rarity, overall unexpectedness and some sort of effective or implied harm. The classical types of occurrences that fall within the boundaries of this definition are natural disasters and industrial accidents. The scope can be broadened to what Birkland calls "deliberately caused catastrophes" (2006), such as terrorist attacks or other kinds of large-scale intentional harms like those taking place in violent conflicts.

Potential focusing effects are prone to attracting attention from the public, politicians and policymakers due to the mechanism of disproportionate information processing, which is a guiding factor both for humans and organisations (Jones 2001). We tend to stick to the status quo in decision-making processes, because a step aside involves the additional investment of time and possibly other resources. This creates a situation where we react to incoming information signals as little as possible, which in practice means underreacting. However, although negative indicators build up and organisations ignore most of the signals delivering such information, a striking piece of information in the form of a focusing event can shake the stability of the status quo. In turn, this will result in overreaction aimed to compensate for the missed opportunities 
(Jones and Baumgartner 2005). The described mechanism presents a long-term perspective of the policy agenda as a sum of many small incremental changes and a bunch of very large punctuations in attention.

However, information signals do not only come from the domestic arena. In an interdependent world where policymaking across all sectors has an international dimension, external focusing events are not weaker competitors for attention. Polities that wish to call themselves global powers in particular need to be alert to crises $^{2}$ happening beyond their territories. Although focusing events are rare occurrences, their number is not negligible on an international scale. For example, in recent years, an average of 16 earthquakes of major and great magnitude (over 7 on the Richter scale) and 145 of strong magnitude (between 6 and 6.9 on the Richter scale) took place annually worldwide. ${ }^{3}$ Meanwhile, the number of terrorist acts in which at least one human being was injured or killed has averaged over 1,700 per year. ${ }^{4}$ These two examples illustrate an abundance of information when it comes to unexpected events that require swift reaction. It seems necessary for political actors to have predefined selection mechanisms and dedicate attention only to those crises that meet certain criteria. Thus, although a potential focusing event can act as a key for unlocking a "window of opportunity" (Kingdon 2011), for a punctuation in attention to materialise, huge constraints need to be overcome. I argue that, for external potential focusing events, these constraints could relate to endogenous and exogenous aspects of the political arena in which events are to be deliberated, as well as to structural capacity conditions.

Scholars of public policy have shown great interest in explaining the influence of focusing events on policy - in particular, the reasons why one crisis results in policy change and others do not (e.g. Nohrstedt 2008; Walgrave and Varone 2008). However, the consequences of potential focusing events for attention, which forms a stage before policy change, are sometimes taken for granted. Further, research in this area is scarce. Scholars have focused on single events, such as the Three Mile Island incident (Baumgartner and Jones 1993) or the 9/11 attacks (Birkland 2004), demonstrating how these cases have acted as reinforcing mechanisms for

\footnotetext{
${ }^{2}$ Some authors advocate a distinction between crises and focusing events (Nohrstedt and Weible 2010), but the dividing line is not entirely clear, and the two are sometimes considered nested categories (Birkland and Nath 2000; Faulkner 2001) or simply referred to interchangeably (Boin et al. 2005). For the purposes of this article, the two concepts are used as synonyms.

${ }^{3}$ According to data for the period 2000-2012 from the Earthquake Hazards Programme of the US Geological Survey, available at http://earthquake.usgs.gov/earthquakes/eqarchives/year/ eqstats.php.

${ }^{4}$ According to data from the RAND Database on Worldwide Terrorism Incidents for the period 2000-2009, available at http://www.rand.org/nsrd/projects/terrorism-incidents.html.
} 
attention being given to the domains with which they are associated and beyond. Studies on specific issue areas have found longitudinal effects of focusing events on these areas (see e.g. Liu et al. 2011 on global climate change). However, overall analyses of the extent to which such events influence institutional agendas are extremely rare. A recent study by van Assche (2012) on the Belgian executive agenda found that some $40 \%$ of the large punctuations in attention are related to focusing events (whereas elections and leadership change seem not to matter). However, the study stops there without digging deeper into the reasons behind the question of why some events made it to the agenda and contributed to the significant increases in attention. The research here aims to take a step in this direction both theoretically and empirically by analysing the latent agenda-setting power of external focusing events in the EU context.

\section{The European Council as a venue for external focusing events}

The European Council originated as an informal body in the mid-1970s because of the necessity to better coordinate common actions and reach agreements on highly conflictual issues that proved difficult for the Council of Ministers (Werts 1992). This essential role for the body did not only pertain to Community action but also to the European Political Co-operation - the predecessor to the Common Foreign and Security Policy. Establishing regular meetings allowed the European Council to address events happening all over the world and to set the EU agenda for positions and further actions (Werts 2008; de Schoutheete 2012). Although specific policy decisions on foreign affairs matters have been made by the Foreign Affairs Council (FAC), ${ }^{5}$ those of highest profile have been reached at the European Council level (Peterson et al. 2012). In fact, the European Council authorises all important decisions within the EU foreign affairs framework. Not surprisingly, it has, therefore, become "the most visible personification of the international identity of the Union" (Soetendorp 1999, 71).

The fact that important current events constitute a key element on the European Council agenda is largely recognised (see e.g. Bulmer and Wessels 1987; Wessels 2008; Princen 2012). External focusing events can also gain access to the EU agenda via the FAC. However, in order to be addressed by the European Council, they need to pass a higher threshold or, in other words, gain priority status. One reason for this is the high political authority of the European Council, which is also related to stronger media

\footnotetext{
5 The Foreign Affairs Council was previously part of the General Affairs Council and used to address internal matters as well. However, international issues were always dominant.
} 
exposure. Therefore, an external focusing event discussed at the FAC level will also be referred to by the Heads of State and Government at their next summit if they regard the matter as substantially important for the Union and want to stress the adopted position. For example, the FAC issued conclusions on the conflict in Mali at its meeting on October 15, 2012, which the European Council endorsed at its summit several days later while additionally emphasising the key points of the EU stance.

Another reason for the more impervious "membrane" of the European Council agenda in comparison with the FAC is the nature of information processing in each of the two bodies. Although the Council configuration is focused on a single policy domain, the institution brings together the Heads of State and Government to discuss a much broader set of issues. Even if international affairs take up a large portion of the agenda (Wessels 2008; Alexandrova et al. 2012), other urgent topics cannot be ignored. Moreover, the FAC is supposed to meet once every month and in fact convenes even more often (Gomez and Peterson 2001), whereas European Council summits are rarer. Specifically, European Council summits took place approximately two to three times a year until the mid-1990s and four to seven times a year ever since, with many informal and extraordinary meetings accounting for this increase. An example illustrating that events have weaker access to the European Council agenda is the Haiti earthquake of January 2010, mentioned in the introduction, which killed over 200,000 and affected some 3.7 million people. The FAC organised an extraordinary meeting following the event to express EU solidarity and signal a commitment to provide assistance. The European Council did not discuss the matter at its next meeting, which was an informal summit dedicated exclusively to the Greek debt crisis. Thus, the highest political authority probably did not recognise the issue as salient enough to call an extraordinary summit or add the point to the next meeting. It was, furthermore, preoccupied with another domestic crisis that had just erupted in the end of 2009.

In short, the European Council is a core venue for discussing EU foreign affairs including external focusing events. It is, furthermore, the institution where the most salient events are placed on the EU agenda, which makes it the most appropriate body for studying the prioritisation of such crises.

\section{The logic of reaction to external focusing events}

Potential focusing events happening abroad often make it to domestic agendas for a variety of reasons. The logic of reacting to external events can be similar to the one employed in domestic cases, as a disaster occurring even at a large distance can add salience to issues that are part of national policy. 
Making analogies is often unavoidable. An example of this is the Fukushima nuclear disaster in Japan in 2011, which became popular news internationally as it raised the issue of nuclear security to the top of the agenda in different countries and the EU (see e.g. Chien 2013). External focusing events can also trigger attention because of the consequences that the event might incur on the relationship between the location of occurrence and the reacting polity. For example, the eruption of the conflict in Mali in 2012 triggered EU attention, as the event was identified as a serious security threat (Cristiani and Fabiani 2013). An event might also be an opportunity for pursuing specific actions that contribute to broad policy goals. The EU sanctions against Syria after the start of the conflict there in 2011 with the core aim of promoting democracy constitute an example of this (Seeberg 2015). These different considerations are not exclusive, and as the interpretation of focusing events is a complex process the reasons for reacting could be multiple.

The logic behind making a decision to address an external focusing event can be understood through aspects that are both exogenous and endogenous to the reacting policy venue. The first category includes the nature of the event and the consequences it brings about. The second category covers factors emanating from the relationship between the foreign country where an event occurred and the domestic polity. Furthermore, structural capacity aspects pertaining to the competition between events and the capacity of the domestic venue's agenda to incorporate new issues have to be considered.

The distinction between endogenous and exogenous aspects resembles the two core notions underlying the debate on foreign aid motivations recipient's need versus donor's interest (Kato 1969; Kaplan 1975; Dudley and Montmarquette 1976; McKinlay and Little 1977, 1978, 1979; McKinlay, 1979). Applying these terms in the present study might be misleading, as they imply a hierarchical relationship between rich powers and poor developing countries that materialises in the form of resource transfer. In the reaction to potential focusing events abroad, such a relationship need not exist. Nevertheless, the literature on foreign aid and disaster assistance constitutes a rich source of relevant determinants of reaction, which can be borrowed and adapted accordingly for the purpose of explaining attention allocation.

Exogenous factors comprise event type and magnitude. Potential focusing events can be classified into two groups - natural and manmade disasters (Birkland 1997, 1998, 2006). Faulkner (2001) elaborates on the meaning of this distinction, discriminating between events induced by the actions or inactions of organisations versus those induced by natural phenomena or external human action. This distinction is similar to Deborah Stone's $(1989,2002)$ classification of human actions as unguided 
or purposeful in her analysis of causal stories. ${ }^{6}$ For example, the recent tsunami in the Philippines in November 2013 can be regarded as a natural disaster. A terrorist attack, like the Istanbul bombings in 2003, on the other hand, represents a purposeful human action that envisaged reaching particular effects. ${ }^{7}$ The basic typology of focusing events can have consequences for political attention due to repercussions on policy. Spending attention is a first step in signalling that policymakers are determined to prevent similar cases in the future, and prevention seems more likely to succeed in manmade accidents (e.g. via civilian or military missions). As Stone notes, "in the natural world the best we can do is to mitigate effects" (Stone 1989, 284), whereas in the realm of purposeful human action impediments for future actions can be designed. Moreover, purposeful activities by individuals are often discussed with the goal of allocating blame, which can later be used in sanctioning. In politics, assigning blame is an instrument to justify actions (Tilly 2008) and as such can be applied to back up existing policies or devise new ones. Therefore:

H1: Manmade incidents should have a higher chance of being discussed than natural disasters in the context of the European Council.

Although by definition the magnitude of a focusing event is considered to be high, the scope varies (Faulkner 2001). The extent of harm can be measured by the number of casualties (dead and injured), damage to property and infrastructure or total cost to the economy (see e.g. Alexander 1997; Birkland 1997; Drury, Olson and Van Belle 2005). Events with a high number of casualties also have strong emotional appeal to the public, which might additionally induce a reaction from political elites. Studies on media coverage of various events (e.g. natural disasters or hazard events) have found that the number of casualties and extent of damage has an effect on the level of reporting (Freudenburg et al. 1996; Van Belle 2000). A similar logic can be applied to political agendas. Although different types of events might be more or less prone to incur damage to housing and infrastructure, the value of human life is probably the most comparable indicator. It does

\footnotetext{
${ }^{6}$ Stone draws a second line of distinction on the extent to which an event is amenable to human intervention or its consequences are intended versus unintended (see also Gundel 2005 for a similar distinction).

${ }^{7}$ Even if it seems straightforward, the distinction between natural and manmade focusing events is not undisputed, because, as Stone points out, different actors attempt to portray the problem associated with the dramatic occurrence via different lenses. Although accounting for such volatility in depiction is crucial when analysing the development of a single issue across venues, considering a fixed typology from the perspective of a single institutional venue does not involve bias. Moreover, most sudden events with large-scale negative effects are framed predominantly as belonging to a single type.
} 
not encompass all potential focusing events but relates to a broad range of cases, such as incidents in conflicts, terrorist attacks and most types of natural disasters. Therefore, we could expect that:

$\mathrm{H} 2$ : The higher the number of people killed as a consequence of a potential focusing event, the higher the likelihood that the event will be featured on the agenda and gain more attention.

Endogenous factors that could influence attention to potential focusing events reflect a certain relationship between the venue addressing the occurrence or its political system broadly and the country/region in which the event takes place. In particular, the decision to pay attention to an event could depend on strategic interests of a geopolitical, security or economic nature (Kato 1969; Kaplan 1975; Dudley and Montmarquette 1976; McKinlay and Little 1977, 1978, 1979; Meernik et al. 1998; Van Belle et al. 2004; Nelson 2012). Although this category includes a large range of theoretically relevant determinants, the logic behind their effect is generally the same. By giving attention to an external event, a polity seeks to render indirect benefits for itself - protect its own citizens, increase its external political influence, further its own economic gains or safeguard its domestic security.

In terms of geopolitics, it seems plausible to expect that catastrophes in immediate or close proximity have an easier time reaching the agenda of the European Council, as the repercussions of such crises can be easily felt. For example, the EU should care more about the wars in former Yugoslavia than any civil wars in sub-Saharan Africa due to the proximity of the threat and the consequences of the conflict, such as refugee flows. Thus, we could expect that:

H3: Potential focusing events occurring in geographically closer countries should be more likely to catch the attention of the European Council.

Geopolitical goals can also relate to ideological positions - notably, the promotion of democracy and democratic values. According to rational thinking, democratic states often support the protection of human rights and civil liberties around the world, because this will deliver long-term stability and peace, which in turn reduces security risks and enhances the opportunities of political and economic gains through cooperation. The question of whether more democratic countries tend to receive higher portions of foreign aid has yielded mixed results in the literature. For example, although Meernik et al. (1998) find evidence for such an effect for US assistance allocations, McKinlay and Little (1979) do not. Yet, the EU has identified the protection and consolidation of democracy, the rule of law and human rights as core values of its development policy. 
These elements are also part of the political criteria for EU membership. This suggests that:

H4: The European Council should be more receptive to focusing events occurring in more democratic countries.

Another materialisation of the rational consideration is the economic side of the relationship. Trade between nations is a key variable in international cooperation. In a recent study conducting a pooled analysis of 22 states (Nelson 2012), larger trade exchanges between countries have been found to underline the decision to grant foreign aid, but individual country examinations provide a more nuanced picture (see e.g. McKinlay 1979). For the EU with its highly developed Common Commercial Policy, such logic might be particularly important. Trade flows between the EU and a state in which a disaster, large-scale accident or conflict happens can be disrupted or at least strained due to the occurrence. For this reason, the EU should be particularly alert to crises in countries with which it trades most. Therefore, we could expect that:

H5: The higher the trade volume between a country and the EU, the stronger the impact a potential focusing event in that country would have on the European Council agenda.

Strategic interests can also be represented by the desire to maintain security in a country where an unexpected crisis disturbs the daily life of citizens. Although a focusing event anywhere abroad could constitute an indirect security threat, states may be more likely to show an interest in their security partners (see e.g. Meernik et al. 1998). The core reason for this is that military allies will be the ones to turn to in the event of major domestic security problems. For the EU, which does not have a defence personality equal to that of nation states, the natural security partners are the co-members of the North Atlantic Treaty Organisation (NATO). Article 4 of the Treaty poses that the parties shall consult with one another when one of them considers its territorial integrity, political independence or security threatened. This means that a focusing event posing a threat to one of the NATO members should evoke attention in all the others. Therefore, we could expect that:

H6: The European Council should be more likely to discuss an external focusing event occurring in non-EU NATO member states.

Besides the exogenous and endogenous factors, structural capacity aspects have to be taken into account. As agenda-setting theories pose, issues compete for attention (Baumgartner and Jones 1993; Jones and Baumgartner 2005), and potential focusing events represent issues with the 
capability to disturb the prescheduled agenda. However, the possibility of addressing a specific crisis might be expected to depend on the number of last-minute intruding elements and the free space for additional agenda points. Therefore, when evaluating the likelihood for an event to appear on the agenda, we need to account for the total number of potential focusing events, thus controlling for the competition between these occurrences. The expectation is that:

H7: The higher the number of potential focusing events at a given point in time, the lower the success rate in agenda access.

We also need to control for the overall number of potential focusing events in individual countries. The more regularly crises occur in a given state, the less likely policymakers might be to allocate attention, as the level of event unexpectedness and rarity might seem lower. Therefore:

H8: The more prone a country is to experience potential focusing events, the lower the chance for events occurring in it to feature on the European Council agenda.

When analysing the share of attention that focusing events receive, the diversity of the agenda needs to be considered. A generally broader range of topics for deliberation suggests lower costs in switching between them. This implies that a more diverse agenda (i.e. containing more items of similar size) is likely to provide more leeway for attention to an additional item compared with an agenda with only a few discussion points of unequal size. Therefore:

H9: The more diverse the European Council agenda, the more attention focusing events should receive.

To sum up, the factors that could theoretically influence the decision to give attention to a particular potential focusing event and the level of this attention can be classified as exogenous and endogenous. The first category encompasses event-specific elements such as type and magnitude. The second category involves factors characterising the relationship between the EU and the country of the event occurrence. EU strategic interests might comprise geopolitical, economic and security considerations. In addition, structural capacity aspects such as a reduced possibility to incorporate new issues in the agenda and competition between potential focusing events might act as attention constraints.

\section{Data and approach}

No unified collection of focusing events exists, but various documented records of specific types of crises have been compiled. Combining elements 
of these allows the creation of a pool approximating a database of possible focusing events on a global scale. This study combined three such collections. The International Emergency Disaster Database was used to record natural disasters and industrial accidents. For measuring the eruptions of violent conflicts, the Uppsala Conflict Data Programme/Peace Research Institute Oslo (UCDP/PRIO) Armed Conflict Dataset was utilised. ${ }^{8}$ The RAND Database on Worldwide Terrorism Incidents provided a list of terrorist attacks. All three data sources contain information on the number of people killed in a potential focusing event and the geographical location of the crisis, and overall cover the period between 1975 and 2012. Exceptions to this include the terrorism data, which ends in 2010, and the records on the number of people killed in violent conflicts, which commence in 1989.

These databases were not developed to trace potential focusing events outside the EU but rather any historical events within a particular domain all over the world. As such, the amount of entries was in some cases quite large, and not all events were relevant for this study. In particular, many incidents were not of a large scale, which is one of the characteristics of a potential focusing event. Therefore, besides excluding cases internal to the $\mathrm{EU}$, the extraction of data from two of the sources was based on scale-related conditions. Disasters were considered when either the number of killed equalled at least 1,000 or the number of affected people corresponded to at least 10,000, yielding 3,615 cases. Terrorist attacks were included in the final sample when the causalities in terms of either injured or killed humans had reached 100, resulting in 184 events. The armed conflicts database was used in full, presenting 926 cases. ${ }^{9}$ The total number of potential focusing events in the final database is 4,725 .

In order to identify the presence of focusing events on the European Council agenda and the attention given to them, a new dataset of the Conclusions issued by this institution after its regular meetings was utilised. ${ }^{10}$ Developed within the EU Policy Agendas Project (Alexandrova et al. 2014), it covers the period 1975-2012 and includes the full text of all Conclusions coded for policy content. ${ }^{11}$ The dataset was extended for the purposes of this article to signify the sections dedicated to or based on the occurrence of focusing events. ${ }^{12}$ This allowed the creation

\footnotetext{
${ }^{8}$ Available at http://www.pcr.uu.se/research/ucdp/datasets/ucdp_prio_armed_conflict_dataset/.

${ }^{9}$ One entry overlapping with the RDWTI data was excluded.

${ }^{10}$ Available at http://www.policyagendas.eu/data.html.

11 The European Council began regular meetings in 1975.

12 A section is not always fully dedicated to a focusing event but often starts with the occurrence and moves further to other issues brought forward by it.
} 
of a pool of all focusing events referred to by the European Council, as well as the detection of the extent of attention each of them received as a share of the whole agenda for a particular meeting.

It should be noted that not all items classified in the European Council Conclusions could be found in the constructed potential focusing events database. For example, the Tanker Amoco Cadiz crash (1978) and the Prestige wreck (2002) that caused large oil spills were not present in the disasters dataset. Another example can be seen in international economic disruptions, such as the financial crisis of 2008 or the oil crises of the 1970s. Although these unintended exclusions limited the pool of focusing events discussed in the European Council, the reduction in data was systematic and should not have affected the final results. Moreover, most of the excluded events were of such types that they did not correspond to the overall measurements of effects. The oil spills, for instance, did not have human casualties but environmental impacts, and the two are clearly not directly comparable.

A few additional sources were consulted in order to identify the EU relationship with countries around the world. Neighbouring countries were considered to consist of all current EU member states before the date of their accession, the countries within the present European Neighbourhood Policy, EFTA members and the candidates or potential candidates for EU membership (states in the Western Balkans and Turkey). NATO membership was also coded as a dummy variable with due regard to the year of accession. The total volume of external trade between the EU and third countries was recorded on an annual basis from Eurostat (available since 1988). ${ }^{13}$ Democracy status was taken from the Freedom House annual index, and was represented by a score of 1 (highest) to 7 (lowest level of freedom) for political rights and civil liberties (averaged). ${ }^{14}$ The variables democracy status and trade exchange were matched with the events with a one-year lag. The two variables on the number of potential focusing events per year and per location were calculated on the basis of the existing data. Agenda diversity was estimated via Shannon's H index, also measured on an annual basis.

It should be noted that the entries in the database corresponded to single events in the case of terrorist attacks and disasters but constituted annual entries for conflicts. Therefore, attention was aggregated in the latter case to reflect yearly discussions. Although this might seem to suggest a lack of

\footnotetext{
${ }^{13}$ Derived from http://epp.eurostat.ec.europa.eu/portal/page/portal/international_trade/data/ database.

${ }^{14}$ Derived from http://www.freedomhouse.org/sites/default/files/Country\%20Ratings\%20and \%20Status\%2C\%201973-2014\%20\%28FINAL\%29.xls.
} 
Table 1. Summary of variables, sources and descriptive statistics

\begin{tabular}{|c|c|c|c|c|c|c|c|c|c|c|c|}
\hline \multirow[b]{2}{*}{ Variable } & \multirow[b]{2}{*}{ Source } & \multicolumn{5}{|c|}{ All Potential Focusing Events } & \multicolumn{5}{|c|}{ Subset Events on the Agenda } \\
\hline & & Observation & $\begin{array}{c}\text { Mean/ } \\
\text { Proportion }\end{array}$ & SD & Minimum & Maximum & Observation & $\begin{array}{c}\text { Mean/ } \\
\text { Proportion }\end{array}$ & SD & Minimum & Maximum \\
\hline $\begin{array}{l}\text { Potential focusing } \\
\text { event (D) }\end{array}$ & $\begin{array}{l}\text { EM-DAT, } \\
\text { UCDP/PRIO } \\
\text { ACD \& } \\
\text { RDWTI }\end{array}$ & 4,725 & 0.021 & 0.142 & 0 & 1 & & & & & \\
\hline $\begin{array}{l}\text { Disasters only } \\
\text { (D) }\end{array}$ & EM-DAT & 3,615 & 0.005 & 0.068 & 0 & 1 & & & & & \\
\hline $\begin{array}{l}\text { Violent acts } \\
\text { only (D) }\end{array}$ & $\begin{array}{l}\text { UCDP/PRIO } \\
\text { ACD \& } \\
\text { RDWTI }\end{array}$ & 1,110 & 0.072 & 0.259 & 0 & 1 & & & & & \\
\hline $\begin{array}{l}\text { Attention to a } \\
\text { focusing event }\end{array}$ & $\begin{array}{l}\text { European } \\
\text { Council } \\
\text { Conclusions, } \\
\text { EUPAP }\end{array}$ & & & & & & 97 & 0.052 & 0.111 & 0.002 & 1 \\
\hline $\begin{array}{l}\text { Number of killed } \\
\text { people (per } \\
1,000)\end{array}$ & $\begin{array}{l}\text { EM-DAT, } \\
\text { UCDP/PRIO } \\
\text { ACD \& } \\
\text { RDWTI }\end{array}$ & 3,837 & 1.069 & 13.506 & 0 & 610 & 96 & 9.574 & 39.061 & 0.008 & 300 \\
\hline $\begin{array}{l}\text { Neighbouring } \\
\text { country (D) }\end{array}$ & $\begin{array}{l}\text { European } \\
\quad \text { Commission }\end{array}$ & 4,725 & 0.084 & 0.277 & 0 & 1 & 97 & 0.443 & 0.499 & 0 & 1 \\
\hline $\begin{array}{l}\text { Democracy status } \\
\qquad(t-1)\end{array}$ & Freedom House & 4,703 & 4.322 & 1.775 & 1 & 7 & 97 & 4.67 & 1.997 & 1 & 7 \\
\hline $\begin{array}{l}\text { External trade } \\
\text { volume }(t-1 \text {, } \\
\text { in million } \\
\text { EUR) }\end{array}$ & Eurostat & 3,932 & 28.144 & 66.817 & 0.001 & 430.058 & 92 & 14.198 & 39.28 & 0.013 & 250.016 \\
\hline
\end{tabular}


Table 1. Continued

\begin{tabular}{|c|c|c|c|c|c|c|c|c|c|c|c|}
\hline \multirow[b]{2}{*}{ Variable } & \multirow[b]{2}{*}{ Source } & \multicolumn{5}{|c|}{ All Potential Focusing Events } & \multicolumn{5}{|c|}{ Subset Events on the Agenda } \\
\hline & & Observation & $\begin{array}{c}\text { Mean/ } \\
\text { Proportion }\end{array}$ & SD & Minimum & Maximum & Observation & $\begin{array}{c}\text { Mean/ } \\
\text { Proportion }\end{array}$ & SD & Minimum & Maximum \\
\hline $\begin{array}{l}\text { NATO } \\
\text { membership } \\
\text { (D) }\end{array}$ & NATO & 4,725 & 0.036 & 0.186 & 0 & 1 & 97 & 0.041 & 0.2 & 0 & 1 \\
\hline $\begin{array}{l}\text { Agenda diversity } \\
\text { (Shannon's H } \\
\text { index) }\end{array}$ & $\begin{array}{l}\text { Own } \\
\text { calculation }\end{array}$ & 4,725 & 2.33 & 0.23 & 1.667 & 2.688 & 97 & 2.336 & 0.186 & 2.022 & 2.688 \\
\hline $\begin{array}{l}\text { Number of } \\
\text { potential } \\
\text { focusing } \\
\text { events/year }\end{array}$ & $\begin{array}{l}\text { Own } \\
\text { calculation }\end{array}$ & 4,725 & 161.476 & 38.821 & 49 & 237 & 97 & 156.454 & 32.242 & 110 & 237 \\
\hline $\begin{array}{l}\text { Number of } \\
\text { potential } \\
\text { focusing } \\
\text { events/country }\end{array}$ & $\begin{array}{l}\text { Own } \\
\text { calculation }\end{array}$ & 4,725 & 126.926 & 133.532 & 0 & 395 & 97 & 52.402 & 65.216 & 1 & 375 \\
\hline
\end{tabular}

Note: D indicates a dummy variable. Neighbouring countries include all current EU member states before the date of their accession, the countries within the present European Neighbourhood Policy, EFTA members and the candidates or potential candidates for EU membership (states in the Western Balkans and Turkey).

EM-DAT = International Emergency Disaster Database; UCDP/PRIO ACD = Uppsala Conflict Data Programme/Peace Research Institute Oslo Armed Conflict Dataset; RDWTI = RAND Database on Worldwide Terrorism Incidents; EUPAP = European Union Policy Agendas Project. 
systematicity, in did not in fact pose a real problem, as yearly violent conflicts represented a sum of a range of incidents. Table 1 presents descriptive statistics for all variables. It does so for the complete dataset of all potential focusing events and the subset of it containing only the pool of focusing events discussed by the European Council.

The analysis of the determinants behind the agenda-setting impact of potential focusing events was carried out in a two-step approach. First, the hypotheses were tested on the full version of the dataset in order to answer the question as to what causes the appearance of focusing events on the European Council agenda. The dependent variable here was dichotomous, indicating whether each of the 4,725 cases was discussed or not. Therefore, a logistic regression was used. ${ }^{15}$ The second step addressed the question of what determines the level of attention a focusing event receives. Here, the dependent variable corresponded to the segment of attention each crisis had been allocated as a share of the total agenda of the respective meeting. Thus, it constituted a subset of only 97 focusing events featured in the full dataset that the European Council effectively discussed. In this case, a fractional logit model was applied, as it is the most suitable method for fractional dependent variables (Papke and Wooldridge 1996).

The two-step approach adopted here is similar to some studies of foreign aid allocation (e.g. McGillivray and Oczkowski 1991, 1992). The decision to spend aid and the actual disbursement of funds are two processes that might - but need not necessarily - depend on each other. In the same line of thinking, the agreement to discuss a potential focusing event in the European Council is separate from the decision on the actual amount of attention the event will receive. Yet, as this theoretical proposition required an empirical validation, a Heckman selection model was run on the data (not shown). This method controlled for the potential bias introduced in the second step of the analysis from the selection of particular events in the first stage. The correlation between the error of the regression equation and the error of the selection equation of the Heckman model $-\rho$ - was not significant, indicating that selection bias was not a significant concern. Therefore, the two-step approach described above was adopted.

\section{Attention to focusing events in the European Council}

The total number of unique focusing events identified in the European Council Conclusions was 114, with 102 of them being external. In over half

\footnotetext{
15 Another option is to use a probit model, which would be equally suitable for the data. As the goodness of fit statistics are quite similar for the fitted models of the two regression types and as the results of a logit model are easier to interpret, the latter was chosen.
} 
of all summits, a crisis of some kind triggered attention. Figure 1 displays the frequency of all external focusing events per meeting. More often, a single event was mentioned, but in a substantive amount of cases the number went up to two or three. Some crises were addressed more than once in consecutive meetings because of the prominence of the issue, its evolving nature (e.g. escalation of a conflict) or both. This brought the total number of external events (unique and repeated ones) discussed in all meetings up to 239.

Nine per cent of all text in the European Council Conclusions was associated with an external focusing event (and an additional $1 \%$ with domestic cases). ${ }^{16}$ Three-fourths of the unique crises were manmade incidents, featuring eruptions of violent conflicts and wars, terrorist attacks and a few specific cases of events like invasions, assassinations, nuclear tests and so on. Floods, tsunamis, earthquakes and famine were among the most common kinds of natural disasters. In six extraordinary and/or informal summits, the whole agenda of the European Council consisted of issues stemming directly from a focusing event. They comprise the $9 / 11$ terrorist attacks, the Iraq disarmament crisis, the start of the Russia-Georgia war, the beginning of the Arab Spring, the Second Intifada in the PalestinianIsraeli conflict and the Fall of the Berlin Wall.

The total number of focusing events incorporated in the final dataset is 97 (see Table 1), and differs from the frequency of focusing events addressed in the Conclusions, 102 unique cases, or 239 in total including repeated ones. Besides the aforementioned exclusion of some events (like oil spills), this discrepancy is due to two reasons. First, in the final dataset, some crises that were mentioned as a single case by the European Council were included as multiple entries because the Conclusions mentioned a region rather than a country, whereas

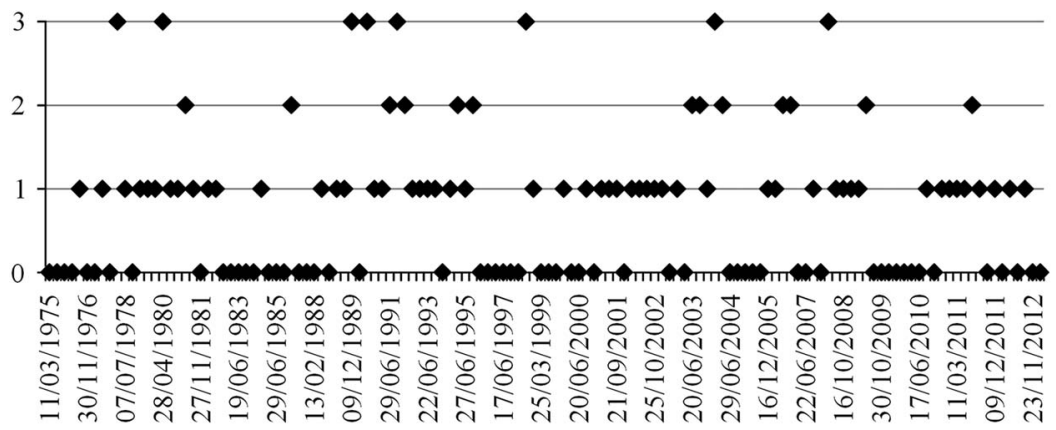

Figure 1 Frequency of unique external focusing events addressed at European Council meetings, 1975-2012.

16 This attention is divided approximately in half between unique and repeated cases. 
the events datasets were organised around individual countries. Examples include hurricane Mitch in Central America in 1998 and the famine in the Sahel region in 1983. Second, some conflict-related events that were repeatedly discussed in the European Council were reduced to a single annual entry due to the structure of the conflict data. Examples include the Second Intifada in the Palestinian-Israeli conflict, which was discussed at three meetings in 2002, and the Syrian Civil War present on the agenda of four summits in 2012.

\section{Analysing the agenda-upsetting effect}

Table 2 presents the results of the logistic regression on the full dataset (model 1). ${ }^{17}$ It appears that both exogenous factors play a role in determining the choice to address a potential focusing event in the European Council. Significant effects are found for event type and the number of people killed. The odds of presence on the agenda are $0.10 \%$ higher for manmade incidents than for natural disasters, all other variables held constant. This highly significant effect of focusing event type requires further consideration, wherefore separate analyses are carried out on subsets of the data containing disasters (model 1A) and violent acts - that is, conflicts and terrorist attacks (model 1B). The effect of the death toll is consistent across the two event types. Thus, with a 1,000 more people killed in an event, the odds of it appearing on the agenda increase by $0.85 \%$ for natural disasters, all other variables held constant (model 1A). For manmade disasters, the increase is $4.15 \%$ (model $1 \mathrm{~B}$ ). Running model 1 with an interaction term for event type and the size of the death toll, and plotting the marginal effects (not shown) for the dichotomous variable, reveals a more nuanced story. Differences are significant only when the number of killed people ranges between about 150,000 and 510,000. For smaller and higher values, the difference is not statistically significant. Thus, conflicts and terrorist attacks are more likely to attract attention than natural disasters when the death toll is neither too small nor extremely large, but rather in a medium range.

Among the exogenous variables, the only one with a significant effect is neighbourhood. Interestingly, the neighbourhood effect seems to be relevant for manmade catastrophes, as natural disasters in the EU neighbourhood did not make it to the agenda in the period 1988-2012. Note that the neighbourhood dummy is not included in model $1 \mathrm{~A}$, as it predicts failure perfectly. ${ }^{18}$ The exclusion of the NATO membership variable is equivalent. Model 1B

\footnotetext{
${ }^{17}$ No problems with multicollinearity were found.

${ }^{18}$ No disasters in the neighbourhood gained attention besides the Chernobyl nuclear reactor explosion, but this case is excluded from the model as there is missing data on the variable external trade.
} 
Table 2. Logistic regression: predicting presence of focusing events on the agenda, 1988-2012

\begin{tabular}{|c|c|c|c|}
\hline & $\begin{array}{l}\text { Model } 1 \\
\text { All Events }\end{array}$ & $\begin{array}{c}\text { Model 1A } \\
\text { Natural Disasters }\end{array}$ & $\begin{array}{c}\text { Model 1B } \\
\text { Humanly Caused Disasters }\end{array}$ \\
\hline Event type (D) & $-2.268(0.303) * * *$ & & \\
\hline Number of killed people (per 1,000 ) & $0.00863(0.00454) *$ & $0.00848(0.00410) * *$ & $0.0415(0.0209) * *$ \\
\hline Neighbouring country (D) & $1.403(0.295)^{* * *}$ & & $1.994(0.354) * * *$ \\
\hline Democracy status $(t-1)$ & $-0.0532(0.0804)$ & $-0.161(0.187)$ & $0.0184(0.0965)$ \\
\hline External trade volume $(t-1$, in million EUR) & $-0.000340(0.00459)$ & $-0.00704(0.0147)$ & $-0.00574(0.00664)$ \\
\hline NATO membership (D) & $-0.817(0.511)$ & & $-0.645(0.532)$ \\
\hline $\begin{array}{l}\text { Number of potential focusing events (FEs)/ } \\
\text { year }\end{array}$ & $-0.0117(0.00470)^{* *}$ & & \\
\hline Number of potential FEs/year (disasters only) & & $-0.0103(0.0116)$ & \\
\hline $\begin{array}{l}\text { Number of potential FEs/year (violent acts } \\
\text { only) }\end{array}$ & & & $0.00604(0.0183)$ \\
\hline Number of potential FEs/country & $-0.00761(0.00280)^{* * *}$ & & \\
\hline $\begin{array}{l}\text { Number of potential FEs/country (disasters } \\
\text { only) }\end{array}$ & & $-0.00974(0.00428)^{* * *}$ & \\
\hline $\begin{array}{l}\text { Number of potential FEs/country (violent acts } \\
\text { only) }\end{array}$ & & & $-0.0117(0.00624)^{*}$ \\
\hline Constant & $-0.177(0.911)$ & $-2.470(1.824)$ & $-3.023(1.067) * * *$ \\
\hline Observations & 3,254 & 2,178 & 1,076 \\
\hline Log pseudo-likelihood & -314.401 & -72.833 & -243.123 \\
\hline Pseudo $R^{2}$ & 0.24 & 0.08 & 0.13 \\
\hline
\end{tabular}

Notes: Robust standard errors in parentheses; D indicates a dummy variable.

NATO $=$ North Atlantic Treaty Organisation.

$* \mathrm{p}<0.10, * * \mathrm{p}<0.05, * * \mathrm{p}<0.01$. 
Table 3. Fractional logit (marginal effects): predicting attention levels to focusing events present on the agenda, 1988-2012

Model 2

All events

Event type (D)

Number of killed people (per 1,000)

$-0.01249(0.0136)$

$0.00024(0.00019)$

Neighbouring country (D)

$0.03013(0.01272)^{* *}$

Democracy status $(t-1)$

$-0.00713(0.00598)$

External trade volume $(t-1$, in million EUR)

$0.00036(0.0002)^{*}$

NATO membership (D)

$-0.02698(0.00867)$

Agenda diversity

$0.06443(0.05772)$

Observations

Log pseudo-likelihood

Deviance

6.817

Notes: Robust standard errors in parentheses; $\mathrm{D}$ indicates a dummy variable. *p $<0.10, * * p<0.05, * *$ p $<0.01$.

shows that, for manmade disasters, the odds of appearing on the agenda are $6.35 \%$ higher in neighbouring countries than in the rest of the world, all other variables held constant. The other strategic interest variables - democracy status, trade volume and NATO membership - do not play a role in the decision for which events to discuss at the summits.

Both structural capacity measures work in the expected direction in the pooled model. The higher the number of potential focusing events occurring in a given year, the less likely the European Council is to select events. The same logic applies to the overall country level. The more often potential focusing events occur in a particular state, the lower the likelihood that events from that country will feature on the agenda. These two relationships show that events compete for attention across both time and space.

Model 2 (Table 3) presents the second step in the analysis - fractional logits on the subset of the data featuring only the focusing events discussed in the European Council. As the coefficients in a fractional logit are not very informative, marginal effects are presented. Unlike in the models predicting the presence of events on the agenda, exogenous factors such as the magnitude and event type do not play a significant role here. The decision on how much attention to dedicate is motivated purely by endogenous explanations of self-interest, particularly geographical proximity and a higher level of trade. Focusing events occurring in neighbouring countries are associated with an increase in attention of 0.05 percentage points 
compared with those in countries from the rest of the world, measured at the predicted European Council attention mean of $3.43 \%$. Stronger trade interchange between the EU and a third country leads to more attention to focusing events in that state once these events are already on the agenda. However, the size of this effect is rather small. A one-unit (i.e. 1 million EUR) increase in the trade volume results in a 0.00036 percentage-point increase in attention at the predicted attention mean of $3.43 \%$. The other two endogenous variables - democratic status and NATO membership - do not have significant effects. The same holds for the level of agenda diversity.

\section{Discussion and conclusions}

Focusing events play an important role in the policy cycle, given their power to reshuffle agendas. However, the number of events that could potentially classify as "focusing" in a given time frame is, in fact, tremendous, and organisations tend to process information disproportionately. Therefore, giving attention to certain policy venues is not a matter of automatic reaction, but rather involves the element of political choice. Allocating attention to events beyond the borders of one's territory might be underscored by exogenous and endogenous factors, as well as affected by structural capacity constraints of the agenda. Starting an enquiry into this decision-making logic with the case study of the $\mathrm{EU}$ is a tough test for disentangling stable logics of impact, as the EU is a polity in the making with sometimes an ambiguous personality in the international arena. A focus on the European Council is justified, as it presents a venue of high political authority with the capacity for immediate reaction to matters of foreign affairs.

Combining data from multiple sources, this study presents the first systematic analysis of the determinants of attention to external focusing events over a period longer than two decades. The first finding is that the decisions regarding the selection of priority events and the allocation of attention are independent of one another and guided by different concerns. Determinants used to choose which potential focusing events appear on the agenda include a mix of exogenous and endogenous factors, highlighting the cohabitation of humanitarian considerations and strategic interests in an environment of competition among events. In particular, events are more powerful agenda-setting factors when they classify as manmade. They also become more powerful with a rise in the number of people killed with one caveat: manmade disasters have an easier time attracting attention in the European Council than natural disasters when the death toll is neither too small nor extremely high. Of the endogenous self-interest variables, 
only neighbourhood appears to have an effect. However, although for violent acts proximity to EU borders increases the likelihood of agenda presence, the location of the event does not play a role for natural disasters. Competition between crises is a constraint for appearance on the agenda both across time and geographical location.

The attention that focusing events receive once they have made it onto the agenda depends upon endogenous factors, indicating a logic grounded exclusively in EU self-interest. Two particular types of strategic EU interests demonstrate significant effects - location and trade volume. The closer a country is to the EU geographically, the more likely it is that events occurring within its territory not only elicit some response from the European Council but also receive a higher portion of its attention eventually. Besides, stronger trade exchange with a given state enhances the likelihood of an event occurring in it to receive more attention, but the effect is rather small. This suggests that a distinguishable increase in attention can be seen only for a range of extremely big economic partners.

These findings offer insight into the EU's role in international relations. The fact that the Union is responsive to focusing events and that these events are considered regularly at the top political level demonstrates a desire for the EU to behave as a global power in world affairs. Yet, its predominant orientation towards the neighbourhood when it comes to addressing violent acts might appear to suggest a regional power perspective. However, this can also be seen as a deliberate choice, for only if the $\mathrm{EU}$ is able to "reinforce dynamics of stability and prosperity in its broader regional context", will it also reinforce its "global standing" (Maurer and Simão 2013, 106).

The neighbourhood predisposition in reacting to violent acts can be interpreted as strategically motivated for two reasons. The aspiration to be seen as a global power in the long run is intertwined with the importance of prevention. Manmade disasters pose multiple direct threats such as a transfer of conflict to EU territory or an increased possibility of terrorist attacks or refugee flows. However, they also have global implications in the context of contemporary security challenges due to the high level of interconnectedness in the world. Thus, reacting to external violent acts presents opportunities for the EU both to protect its own territory and citizens from immediate negative consequences and to position itself in international affairs.

The generally soft image of Europe in world politics is reconfirmed by the importance of the level of causalities in disasters as a key factor in determining whether to discuss events, no matter if they are natural or manmade. This is satisfactory from a normative point of view, but also has its limits. Notably, there is a sort of disaster fatigue associated with the 
country of origin, as the regular occurrence of potential focusing events in a given state limits the chance for attention to be given by the EU leaders to particular cases from that state. Although this confirms the presence of a bounded rationality constraint, it also hints at a sort of balancing in the selection across the globe because of the EU's desire for international visibility.

The findings here add to the literature on the politics of attention. The significant effects of bounded rationality constraints in the agenda presence models provide evidence for a major claim in agenda-setting theories scarcity of attention. The more information signals float in the environment, the lower the chance for each of them to gain access to the political agenda. This chance is also lower when more information signals keep coming from the same external location. Thus, in the foreign affairs part of the agenda, issue competition takes place both across time and space. There is a limit to the permeability of the agenda "membrane", and more intruding information only makes selection harder without offering new possibilities for access. Interestingly, however, bounded rationality has an effect only on the issue selection phase and not on the final allocation of attention.

This study has laid the basis for theorising on the logic of responsiveness to focusing events in the EU and beyond. The distinction between potential and effective focusing events proves to be an important one, as the transformation of the first into the second is not automatic but rather is underscored by specific considerations. The literature on foreign aid and disaster assistance provides valuable insights for theory building. However, the selection of the venue for responsiveness is crucial for the kind of expectations one can suggest on attention dynamics. Further research should test the "successful ingredients" for the agenda-setting impact of potential and effective focusing events on other political systems. It should also concentrate on developing a more fine-grained measure of magnitude that can incorporate types of events excluded in this article, such as oil spills. With the creation of new event datasets, it might become possible to further differentiate the dichotomous events typology applied here, which may yield useful evidence for the policymaking responses beyond the agenda-setting stage.

\section{Acknowledgements}

I thank Arco Timmermans, Sebastian Princen, Jale Tosun and the anonymous reviewers for their helpful comments. An earlier version of this study is part of the author's dissertation: Agenda Setting in the European Council. 


\section{References}

Alexander D. (1997) The Study of Natural Disasters, 1977-1997: Some Reflections on a Changing Field of Knowledge. Disasters 21(4): 284-304.

Alexandrova P., Carammia M., Princen S. and Timmermans A. (2014) Measuring the European Council Agenda: Introducing a New Approach and Dataset. European Union Politics 15(1): 152-167.

Alexandrova P., Carammia M. and Timmermans A. (2012) Policy Punctuations and Issue Diversity on the European Council Agenda. Policy Studies Journal 40(1): 69-88.

Baumgartner F. R. and Jones B. D. (1993) Agendas and Instability in American Politics. Chicago, IL: University of Chicago Press.

Birkland T. A. (1997) After Disaster: Agenda Setting, Public Policy, and Focusing Events. Washington: Georgetown University Press.

- (1998) Focusing Events, Mobilization, and Agenda Setting. Journal of Public Policy 18(1): 53-74.

- (2004) "The World Changed Today": Agenda-Setting and Policy Change in the Wake of the September 11 Terrorist Attacks. Review of Policy Research 21(2): 179-200.

(2006) Lessons of Disaster: Policy Change After Catastrophic Events. Washington, DC: Georgetown University Press.

Birkland T. A. and Nath R. (2000) Business and Political Dimensions in Disaster Management. Journal of Public Policy 20(3): 275-303.

Boin A., t'Hart P., Stern E. and Sundelius B. (2005) The Politics of Crisis Management. Cambridge: Cambridge University Press.

Bulmer S. and Wessels W. (1987) The European Council: Decision-Making in European Politics. Basingstoke: The Macmillan Press Ltd.

Chien H. (2013) Policy Change Or Policy Intractability in Post-Crisis Landscape? The Fukushima Explosion and Comparative Nuclear Energy Policy. Public Administration and Policy 56: $117-146$.

Cristiani D. and Fabiani R. (2013) The Malian Crisis and its Actors. The International Spectator 48(3): 78-97.

de Schoutheete P. (2012) The European Council. In Peterson J. and Shackleton M. (eds.), The Institutions of the European Union, 3rd ed. Oxford: Oxford University Press, 43-67.

Downs A. (1972) Up and Down with Ecology: The "Issue-Attention Cycle". Public Interest 28: $38-50$.

Drury A. C., Olson R. S. and Van Belle D. A. (2005) The Politics of Humanitarian Aid: US Foreign Disaster Assistance, 1964-1995. Journal of Politics 67(2): 454-473.

Dudley L. and Montmarquette C. (1976) A Model of the Supply of Bilateral Foreign Aid. American Economic Review 66(1): 132-142.

Faulkner B. (2001) Towards a Framework for Tourism Disaster Management. Tourism Management 22(2): 135-147.

Freudenburg W. R., Coleman C., Gonzales J. and Helgeland C. (1996) Media Coverage of Hazard Events: Analyzing the Assumptions. Risk Analysis 16(1): 31-42.

Gomez R. and Peterson J. (2001) The EU's Impossibly Busy Foreign Ministers: 'No One is in Control'. European Foreign Affairs Review 6(1): 53-74.

Gundel S. (2005) Towards a New Typology of Crises. Journal of Contingencies and Crisis Management 13(3): 106-115.

Jones B. D. (2001) Politics and the Architecture of Choice. Chicago: University of Chicago Press. 
Jones B. D. and Baumgartner F. R. (2005) The Politics of Attention. How Government Prioritizes Problems. Chicago: University of Chicago Press.

Kaplan S. S. (1975) The Distribution of Aid to Latin America: A Cross-National Aggregate Data and Time Series Analysis. The Journal of Developing Areas 10(1): 37-60.

Kato M. (1969) A Model of US Foreign Aid Allocation: An Application of a Rational DecisionMaking Scheme. In Mueller J. E. (ed.), Approaches to Measurement in International Relations. New York: Appleton-Century-Crofts, 198-215.

Kingdon J. W. (2011) Agendas, Alternatives and Public Policies, 2nd ed., updated. Boston, MA: Longman.

Liu X., Lindquist E. and Vedlitz A. (2011) Explaining Media and Congressional Attention to Global Climate Change, 1969-2005: An Empirical Test of Agenda-Setting Theory. Political Research Quarterly 64(2): 405-419.

Maurer H. and Simão L. (2013) From Regional Power to Global Power? The European Neighbourhood Policy After the Lisbon Treaty. In Boening A., Kremer J. and van Loon A. (eds.), Global Power Europe - Vol. 1. Theoretical and Institutional Approaches to the EU's External Relations. Heidelberg: Springer, 93-108.

McGillivray M. and Oczkowski E. (1991) Modelling the Allocation of Australian Bilaterial Aid: A Two-Part Sample Selection Approach. Economic Record 67(2): 147-152.

(1992) A Two-Part Sample Selection Model of British Bilateral Foreign Aid Allocation. Applied Economics 24(12): 1311-1319.

McKinlay R. D. (1979) The Aid Relationship: A Foreign Policy Model and Interpretation of the Distributions of Official Bilateral Economic Aid of the United States, the United Kingdom, France, and Germany, 1960-1970. Comparative Political Studies 11(4): 411-464.

McKinlay R. D. and Little R. (1977) A Foreign Policy Model of U.S. Bilateral Aid Allocation. World Politics 30(1): 58-86.

(1978) A Foreign-Policy Model of the Distribution of British Bilateral Aid, 1960-70.

British Journal of Political Science 8(3): 313-331.

(1979) The US Aid Relationship: A Test of the Recipient Need and the Donor Interest Model. Political Studies 27(2): 236-250.

Meernik J., Krueger E. L. and Poe S. C. (1998) Testing Models of U.S. Foreign Policy: Foreign Aid during and After the Cold War. The Journal of Politics 60(1): 63-85.

Nelson T. (2012) Determinants of Disaster Aid: Donor Interest or Recipient Need? Global Change, Peace \& Security 24(1): 109-126.

Nohrstedt D. (2008) The Politics of Crisis Policymaking: Chernobyl and Swedish Nuclear Energy Policy. Policy Studies Journal 36(2): 257-278.

Nohrstedt D. and Weible C. M. (2010) The Logic of Policy Change After Crisis: Proximity and Subsystem Interaction. Risk, Hazards \& Crisis in Public Policy 1(2): 1-32.

Papke L. E. and Wooldridge J. M. (1996) Econometric Methods for Fractional Response Variables with an Application to 401(K) Plan Participation Rates. Journal of Applied Econometrics 11(6): 619-632.

Peterson J., Byrne A. and Helwig N. (2012) International Interests: The Common Foreign and Security Policy. In Peterson J. and Shackleton M. (eds.), The Institutions of the European Union, 3rd ed. Oxford: Oxford University Press, 288-314.

Princen S. (2011) Agenda-Setting Strategies in EU Policy Processes. Journal of European Public Policy 18(7): 927-943.

(2012) Agenda-Setting and the Formation of an EU Policy-Making State. In Richardson J. (ed.), Constructing a Policy-Making State?: Policy Dynamics in the EU. Oxford: Oxford University Press, 29-45. 
Seeberg P. (2015) The EU and the Syrian Crisis: The Use of Sanctions and the Regime's Strategy for Survival. Mediterranean Politics 20(1): 18-35.

Soetendorp B. (1999) Foreign Policy in the European Union: Theory, History and Practice Vol. 19. London: Longman.

Stone D. (2002) Policy Paradox. The Art of Political Decision Making, 2nd ed. New York: W. W. Norton \& Company.

Stone D. A. (1989) Causal Stories and the Formation of Policy Agendas. Political Science Quarterly 104(2): 281-300.

Tilly C. (2008) Credit and Blame. Princeton: Princeton University Press.

Van Assche T. (2012) When do New Issues Appear? Punctuations in the Belgian Executive Agenda. Acta Politica 47(2): 128-150.

Van Belle D. A. (2000) New York Times and Network TV News Coverage of Foreign Disasters: The Significance of the Insignificant Variables. Journalism \& Mass Communication Quarterly 77(1): 50-70.

Van Belle D. A., Rioux J. and Potter D. M. (2004) Media, Bureaucracies, and Foreign Aid: A Comparative Analysis of United States, the United Kingdom, Canada, France and Japan. New York: Palgrave Macmillan.

Walgrave S. and Varone F. (2008) Punctuated Equilibrium and Agenda-Setting: Bringing Parties Back in: Policy Change After the Dutroux Crisis in Belgium. Governance 21(3): 365-395.

Werts J. (1992) The European Council. Amsterdam: North Holland Elsevier Science Publishers B.V.

- (2008) The European Council. London: John Harper Publishing.

Wessels W. (2008) The European Council: A Bigger Club, a Similar Role?. In Best E., Christiansen T. and Settembri P. (eds.), The Institutions of the Enlarged European Union: Continuity and Change. Cheltenham: Edward Elgar, 16-33. 